\title{
O tym, jak Hus stał się Husem albo droga życiowa czeskiego reformatora w dwudziestu rozdziałach
}

\author{
František Šmahel, Jan Hus. Život a dílo, Argo, \\ Praha 2013, 312 s.
}

W 2015 roku będziemy obchodzić sześćsetletnią rocznicę śmierci Jana Husa - postaci, która odcisnęła wyraźny ślad nie tylko na czeskiej, ale i na europejskiej historii późnego średniowiecza. W związku z jubileuszem można się spodziewać ożywionego zainteresowania czeskim reformatorem w pracach naukowych i w publicystyce. W 2013 roku wydawnictwo Argo, wyprzedzając niejako oczekiwane zapotrzebowanie, wydało książkę Jan Hus. Život a dílo autorstwa wybitnego czeskiego mediewisty i znawcy epoki husyckiej Františka Šmahela (1934).

Ambicją autora, czego można się dowiedzieć ze wstępu, nie było napisanie „wielkiej” monografii naukowej. Powstała pozycja, która łączy cechy tekstu naukowego i popularyzatorskiego. Praca jest napisana przystępnym językiem, jednocześnie jednak autor nie unika podejmowania niełatwych dla laika zagadnień, takich jak subtelne kwestie średniowiecznej scholastyki i dogmatyki: bez - chociażby elementarnego - poznania ich, trudno zrozumieć poglądy Husa teologa oraz istotę jego sporu z instytucjonalnym Kościołem.

W dwudziestu chronologicznie ułożonych rozdziałach autor przedstawia losy, poglądy, postawy oraz - niejednokrotnie trudne i fatalne w skutkach - decyzje praskiego kaznodziei. Czytelnik może śledzić ,jak Hus stopniowo stawał się Husem", czyli jak kształtowała się jego droga życiowa. Przełomowe okazały się cztery lata: rok 1402, kiedy Hus został kaznodzieją w Kaplicy Betlejemskiej - późniejszym głównym ośrodku czeskiej myśli reformacyjnej - i mniej więcej w tym samym czasie zapoznał się 
z pracami angielskiego teologa i filozofa Jana Wiklefa; rok 1409, gdy po wydaniu przez czeskiego króla Wacława IV tzw. dekretu kutnohorskiego, który w istotny sposób zmienił system głosowania na Uniwersytecie Praskim na korzyść narodu czeskiego (korporacji uniwersyteckiej), został rektorem tejże uczelni oraz czołową postacią czeskiej reformacji; rok 1412, kiedy jako bezkompromisowy krytyk handlu odpustami utracił poparcie nie tylko władz kościelnych, ale także króla, zdecydował się na kontynuację sporu z hierarchią kościelną i znalazł się na drodze bez odwrotu, prowadzącej nieuchronnie do tragicznego finału. Śmierć Jana Husa przez spalenie na stosie 6 lipca 1415 roku oznaczała początek jego drugiego życia - dla jednych adorowanego męczennika i bohatera narodowego, dla innych heretyka godnego potępienia.

Wśród dwudziestu rozdziałów na szczególną uwagę zasługują te, które przerywają tok opowieści i zatrzymując się przy bardziej szczegółowych zagadnieniach życiorysu Husa pokazują go w innym niż dotychczas świetle. W rozdziale X (Husův kvodlibet a jeho loučenís univerzitou) czytelnik może bliżej poznać bohatera książki jako wykładowcę uniwersyteckiego (uniwersytet stanowił jego środowisko przez większą część życia) - prowadzącego w styczniu 1411 roku doroczną dysputację naukową na Wydziale Artystycznym, tzw. quodlibet. Z zachowanych notatek dokumentujących przygotowania do prowadzenia debaty (wykładowca musiał pokrótce przedstawić każdego z uczestników i opracować dla niego kwestię do rozważań) wyłania się „nowy”, nieznany opinii publicznej, Hus. Nie jest to patetyczny wizjoner (uwieczniony na pomniku na Rynku Staromiejskim w Pradze), lecz błyskotliwy, dowcipny a także subtelnie ironiczny retor.

$\mathrm{Na}$ uwagę zasługuje także rozdział XIII (Znameníčka, ukazovadla, nápisy a šifry). Powszechnie wiadomo, że twórczość literacka Husa w języku czeskim (np. katechizacyjne teksty Výklad viery, Desatera a Páte$\check{r}$, ale także jego bogata korespondencja) zapewniła mu trwałe miejsce w historii języka i literatury narodowej. Prawdopodobnie miał swój udział w drugiej redakcji czeskiego przekładu Biblii, przypisuje mu się także autorstwo traktatu Ortographia Bohemica, zawierającego zasady pisowni diakrytycznej czeskich tekstów. Mniej znany jest fakt, że Hus jako prekursor literatury teologicznej w języku czeskim zaprowadził, na potrzeby pracy z Biblią, przejrzyste reguły cytacji oraz indeksacji. 
Trudno sobie wyobrazić nowoczesną monografię o Janie Husie, która, chociażby w zarysie, nie zajmowałaby się także drugim życiem czeskiego reformatora $\mathrm{i}$ jego zmiennym obrazem historycznym. Šmahel poświęca tej kwestii ostatni rozdział książki. Lista biografów Husa jest długa (autor dedykuje książkę najwybitniejszym z nich, m.in. Petrowi z Mladoňovic, Františkowi Palackiemu, Janowi Sedlákowi, Václavowi Novotnemu czy Paulowi de Vooghtowi) i zawiera twórców żyjących między XV stuleciem a współczesnością. Poszczególne dzieła reprezentują spektrum poglądów uwarunkowanych konfesyjnie (w przypadku starszych tekstów), historiozoficznie, światopoglądowo lub ideologicznie (w przypadku tekstów reprezentujących czasy najnowsze). Dla współczesnej historiografii, uwzględniającej dotychczasowy dorobek i kierującej się zasadą obiektywnego oglądu wydarzeń historycznych oznacza to potrzebę dociekania ,jak było naprawdę”. Taki chłodny obiektywizm, zdaniem Šmahela, nie zawsze jednak jest możliwy czy nawet pożądany. Historyk badający np. proces sądowy, który toczył się przeciwko Husowi w Konstancji, może obiektywnie stwierdzić, że odbył się on zgodnie z ówczesnym prawem kanonicznym, co jednak nie pozbawia go prawa do moralnego osądu, w którego świetle w tym przypadku złamano prawo człowieka do swobodnego wyrażania opinii. Ofiara Husa, poniesiona w celu obrony praw jednostki odbieranych jej przez instytucjonalną władzę, pozostaje w swoim metahistorycznym wydźwięku trwałym przykładem odważnego czynu połączonego z oryginalną myślą.

Trzeba podkreślić, że autor, chociaż nie ukrywa fascynacji Janem Husem, nie koloryzuje jego obrazu historycznego. Badanie Husa i jego epoki jest dla Šmahela tematem, który nie przestaje frapować i skłaniać do zadawania nowych pytań, o czym świadczy aneks zamieszczony na końcu książki - przegląd wybranych zagadnień i stanu badań nad Husem (s. 261-271), które dotyczą nieraz rozwijanej od wieków husowskiej mitologii. Warto tu wymienić np. dyskusje wokół miejsca urodzenia Husa, niektórzy badacze bowiem podważają tradycyjnie podawany południowoczeski Husinec; przykładem mityzacji praskiego kaznodziei jest jego całkowicie fikcyjny, utrwalony przez tradycję, wizerunek brodatego kaznodziei protestanckiego. Współczesna historiografia stara się również o bardziej wyważone przedstawienie procesu sądowego toczącego się przeciwko Husowi w Konstancji, który można oceniać z różnych punktów widzenia: prawnego, politycznego, ale także moralnego. 
Książka F. Šmahela z pewnością otwiera serię pozycji naukowych, które będą towarzyszyć nadchodzącemu jubileuszowi. Zainteresowanie powinno budzić również jej echo publicystyczne, które pokaże, czy dziedzictwo husowskie jest nadal aktualnym i inspirującym składnikiem czeskiej tożsamości historycznej.

Jan Pešina 